\title{
Evolutionary response to the Qinghai-Tibetan Plateau uplift: phylogeny and biogeography of Ammopiptanthus and tribe Thermopsideae (Fabaceae)
}

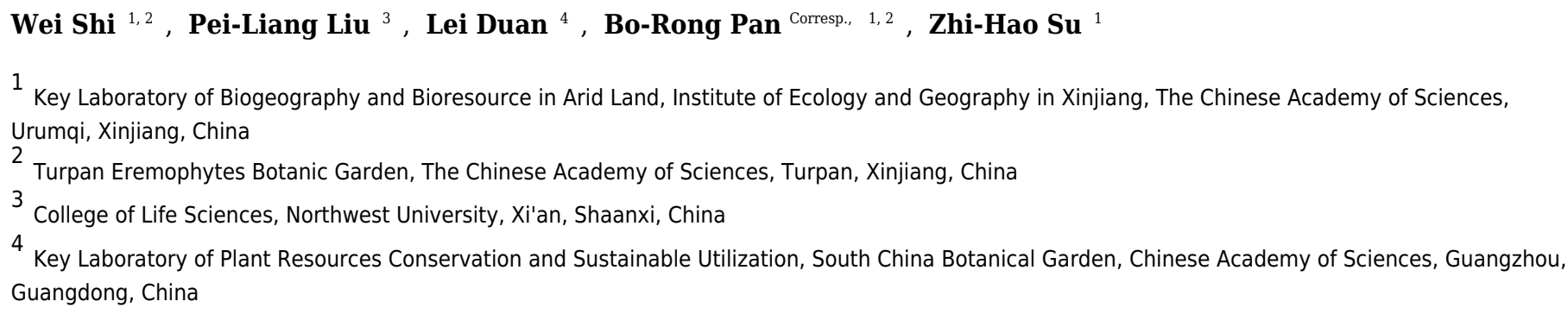

Previous works resolved diverse phylogenetic positions for genera of the Fabaceae tribe Thermopsideae, without a thoroughly biogeography study. Based on sequence data from nuclear ITS and four cpDNA regions (matK, rbcL, trnH-psbA, trnL-trnF) mainly sourced from GenBank, the phylogeny of tribe Thermopsideae was inferred. Our analyses support the genera of Thermopsideae, with the exclusion of Pickeringia, being merged into a monophyletic Sophoreae. Genera of Sophoreae were assigned into the Thermopsoid clade and Sophoroid clade. Monophyly of Anagyris, Baptisia and Piptanthus were supported in the Thermopsoid clade. However, the genera Thermopsis and Sophora were resolved to be polyphyly, which require comprehensive taxonomic revisions. Interestingly, Ammopiptanthus, consisting of $A$. mongolicus and $A$. nanus, nested within the Sophoroid clade, with Salweenia as its sister. Ammopiptanthus and Salweenia have a disjunct distribution in the deserts of northwestern China and the Hengduan Mountains, respectively. Divergence age was estimated based on the ITS phylogenetic analysis. Emergence of the common ancestor of Ammopiptanthus and Salweenia, divergence between these two genera and the split of Ammopiptanthus species occurred at approximately $26.96 \mathrm{Ma}, 4.74 \mathrm{Ma}$ and $2.04 \mathrm{Ma}$, respectively, which may be in response to the second, third and fourth main uplifts of the Qinghai-Tibetan Plateau, respectively. 
1 Evolutionary response to the Qinghai-Tibetan Plateau uplift: phylogeny and biogeography

2 of Ammopiptanthus and tribe Thermopsideae (Fabaceae)

3

4 Wei Shi ${ }^{1,2^{*}}$, Pei-Liang Liu ${ }^{3 *}$, Lei Duan ${ }^{4 *}$, Bo-Rong Pan ${ }^{\text {corresp., }, 1,2}$, Zhi-Hao Su${ }^{1}$

5 Correspondence to B.-R. Pan (brpan@ms.xjb.ac.cn)

$6{ }^{1}$ Key Laboratory of Biogeography and Bioresources in Arid Land, Institute of Ecology and

7 Geography in Xinjiang, The Chinese Academy of Sciences, 830011 Urumqi, China

$8{ }^{2}$ Turpan Eremophytes Botanic Garden, The Chinese Academy of Sciences, 838008 Turpan,

9 China

$10{ }^{3}$ College of Life Sciences, Northwest University, 710069 Xi'an, China

$11{ }^{4}$ Key Laboratory of Plant Resources Conservation and Sustainable Utilization, South China

12 Botanical Garden, Chinese Academy of Sciences, 510650 Guangzhou, China

$13 *$ These authors contributed equally to this work. 


\section{Abstract:}

Previous works resolved diverse phylogenetic positions for genera of the Fabaceae tribe

17 Thermopsideae, without a thoroughly biogeography study. Based on sequence data from nuclear

ITS and four cpDNA regions ( $m a t K, r b c L, \operatorname{trnH}-p s b A, \operatorname{trnL}-\operatorname{trnF}$ ) mainly sourced from GenBank,

the phylogeny of tribe Thermopsideae was inferred. Our analyses support the genera of

Thermopsideae, with the exclusion of Pickeringia, being merged into a monophyletic Sophoreae.

21 Genera of Sophoreae were assigned into the Thermopsoid clade and Sophoroid clade.

Monophyly of Anagyris, Baptisia and Piptanthus were supported in the Thermopsoid clade.

However, the genera Thermopsis and Sophora were resolved to be polyphyly, which require

comprehensive taxonomic revisions. Interestingly, Ammopiptanthus, consisting of A. mongolicus

and A. nanus, nested within the Sophoroid clade, with Salweenia as its sister. Ammopiptanthus

and Salweenia have a disjunct distribution in the deserts of northwestern China and the

Hengduan Mountains, respectively. Divergence age was estimated based on the ITS

phylogenetic analysis. Emergence of the common ancestor of Ammopiptanthus and Salweenia, 
31 second, third and fourth main uplifts of the Qinghai-Tibetan Plateau, respectively.

\section{Introduction:}

33 Thermopsideae (Yakovlev 1972) is a small tribe in Fabaceae, comprising six genera,

34 Ammopiptanthus S.H. Cheng, Anagyris L., Baptisia Vent., Pickeringia Nutt. ex Torr. \& A. Gray,

35 Piptanthus Sweet and Thermopsis R.Br. ex W.T. Aiton, with a total of ca. 45 species.

36 Thermopsideae ranges from the Mediterranean Basin, central and northeastern Asia to temperate

37 North America (Lock 2005; Turner 1981; Wang 2001). Early phylogenetic works supported that the genera composing Thermopsideae, except for Pickeringia, were nested in the "core

39 Genistoids" group, which always contains quinolizidine alkaloids (Crisp et al. 2000;

40 Wojciechowski et al. 2004). A subsequent study conducted by Wang et al. (2006) resolved two

41 clades in this tribe: the genus Ammopiptanthus clade and the "core genera" clade, consisting of

42 Anagyris, Baptisia, Piptanthus and Thermopsis. However, Thermopsideae was not monophyletic,

43 because Sophora nested within this tribe. Based on the plastid marker matK, recent analyses

44 conducted by Cardoso et al. (2012a, 2013) treated the five genera of Thermopsideae,

45 Ammopiptanthus, Anagyris, Baptisia, Piptanthus and Thermopsis, into a narrowly defined tribe

46 Sophoreae. However, Zhang et al. (2015a) accepted the tribe Thermopsideae and their two 
47 phylogenetic trees showed different positions of Sophora. The monophyly and genera included

48 in the tribe Thermopsideae are thus controversial and the relationship between Thermopsideae

49 and Sophora remains unclear. Within Thermopsideae, Anagyris (Ortega-Olivencia 2009),

50 Baptisia (Larisey 1940a; Turner 2006), Pickeringia (Wojciechowski 2013), Piptanthus (Turner

51 1980; Wei 1998; Wei \& Lock 2010) and Thermopsis (Chen et al. 1994; Czefranova 1970;

52 Larisey 1940b; Peng 1992; Sa 1999; Sa 2000) were studied taxonomically, phylogenetically and

53 biogeographically.

54 Within Thermopsieae, Ammopiptanthus is a small genus, established by Cheng (1959) on

55 the basis of $A$. mongolicus (Maxim.) Cheng. and A. nanus (M. Pop.) Cheng f., and being widely

56 accepted (Yakovlev 1988; Yakovlev et al. 1996; Wei 1998). But Wei \& Lock (2010) unified the

57 two species. Although some phylogenetic studies indicated a well-supported Ammopiptanthus

58 (Cardoso et al. 2013; Wang et al. 2006), the infra- and inter-generic phylogeny of this genus

59 needs further research. Zhang et al. (2015a) inferred a diverging time for Ammopiptanthus from

60 the "core Genera" clade, but some closely related Sophoreae genera were not sampled (see

61 Cardoso et al. 2013; Wang et al. 2006), which may have affected the accuracy of the dating.

62 The effects of geological and climatic factors play a key role in the spatiotemporal 
63 evolution of plants (Meng et al. 2017). The uplifts of the Qinghai-Tibetan Plateau (QTP) lead to

64 a long-term climate oscillation in central and northern Asia. At 45-30 Ma, the collision of the

65 Indian plate and the Asian plate triggered the first uplifting of the QTP, the Himalayan orogeny

66 and the retreat of the Tethys (Harrison et al. 1992; Shi et al. 1999); the second main uplift (ca. 25

$67 \mathrm{Ma}$ ) changed the planetary wind system and initiated the Asian monsoon (Chen et al. 1999; Li

68 2001; Shi et al. 1998, 1999; Teng et al. 1997). The third (7-8 Ma; Harrison et al. 1992; Liu et al.

69 2001; Wang et al. 2008; Zheng \& Yao 2006) and fourth uplifting of QTP (3.6-2.5 Ma; Chen et

70 al. 1999; Li \& Fang 1999; Li 2001; Tang \& Liu 2001; Zheng \& Yao 2006) rendered the Asian

71 interior cooler and drier, so evergreen forests vanished. The Tertiary broadleaf forest in Central

72 Asia was taken over by drought-withstanding shrubs and herbs (Meng et al. 2015).

Two species of Ammopiptanthus disjunctively distributed in the southwestern Mongolian

Plateau and the southwestern Pamir Plateau (Wei 1998). Liu et al. (1996) suggested that the ancestor of this genus emerged in the southern hemisphere, dispersing northwards when the

76 Tertiary forest expanded due to the uplift of the QTP and the retreat of the Tethys. Subsequent studies postulated a southern Laurasian origin for Ammopiptanthus and regarded this genus as a relic of the Tertiary flora (Sun 2002a; Sun \& Li 2003; Wang 2001). Based on molecular 
79 evidence, Wang et al. (2006) and Zhang et al. (2015a) supported the relic status postulated for

80 Ammopiptanthus, proposing that its ancestral area was in central Asia. However, the existing

81 phylogeny-based biogeographic analyses used an inadequate sample of the tribe Sophoreae,

82 which is closely related to Thermopsideae (Cardoso et al. 2012a; Cardoso et al. 2013; Azani et al.

83 2017), leading to possible inaccuracies in the bioinformatic inferences.

84 We herein employ existing GenBank sequences and newly generated sequences of the

85 nuclear ITS and the plastid matK, $r b c L, t r n L-t r n F$ and $p s b A$-trnH gene regions, with an extensive sampling for Thermopsideae and Sophoreae, to a) test the monophyly and systematic status of

87 Thermopsideae; and b) infer the phylogeny and biogeography of Ammopiptanthus.

Materials and methods

\section{Sampling scheme}

91

Nine haplotypes of the two species of Ammopiptanthus found by Su et al. (2016) were

92 included in the present study. Both species of Salweenia Baker f. were sampled (Yue et al. 2011).

93 The nuclear internal transcribed spacer (ITS) sequences for Salweenia wardii Baker f. and

94 Maackia amurensis Rupr. and the plastid $p s b A$-trnH and $\operatorname{trn} L$-trnF intergenic spacer sequences 
95 for Maackia amurensis were generated for the present study. The DNA extraction, amplification

96 and sequencing methods followed Su et al. (2016). All other ITS, matK, rbcL, trnL-trnF and

97 psbA-trnH sequences were obtained from GenBank. Guided by the phylogenetic analyses of

98 Ammopiptanthus by Wang et al. (2006) and Zhang et al. (2015a), and the phylogeny of the

99 Genistoids s.1. (Cardoso et al. 2012b; Crisp et al. 2000; Pennington et al. 2001; Peters et al. 2010;

100 Wojciechowski 2003), we included all the available species of Thermopsideae and Sophoreae s.s.

101 in our analyses. In total, we sampled 21 species in Thermopsis, seven species of Piptanthus, two

102 species of Anagryris, six species of Bapstisia, 13 species of Sophora, three species in Maackia,

103 two species in Euchresta and one species in each of the following genera: Ammodendron,

104 Ammothamnus and Echinosophora. Some other species of the Genistoids s.l. were also selected

105 according to previous phylogenetic frameworks (Cardoso et al., 2012b, 2013). Ormosia was set

106 as the outgroup. The specific taxa, including their GenBank accession numbers, are shown in

107 Table 1.

108 Phylogenetic analyses

109 Multiple sequence alignments were performed using MUSCLE (Edgar 2004) in the

110 Geneious v.8.1.2 platform (Kearse et al. 2012) with default settings and manual adjustments. The 
111 best-fit substitution models for the ITS1, 5.8S, ITS2, matK, psbA-trnH, rbcL and trnL-trnF

112 regions were determined separately using jModelTest v.2.1.7 (Darriba et al. 2012). Phylogenetic

113 relationships were inferred using Bayesian inference (BI) as implemented in MrBayes v.3.2.5

114 (Ronquist \& Huelsenbeck 2003) and maximum likelihood (ML) analysis with RAxML v.8.2

115 (Stamatakis 2014). The nuclear ITS dataset was partitioned into ITS1, 5.8S and ITS2 partitions.

116 For the concatenated plastid dataset, data was partitioned separately for $m a t K, p s b A-t r n H, r b c L$

117 and $\operatorname{trn} L-\operatorname{trnF}$. Two independent analyses for BI were conducted, with one cold and three

118 incrementally heated Markov chain Monte Carlo (MCMC) chains run for 10,000,000 generations.

119 Trees were sampled every 1,000 generations. All Bayesian analyses produced split frequencies

120 of less than 0.01 , showing convergence between the paired runs. The first 2,500 trees were

121 discarded as burn-in and the remaining trees were used to construct a 50\% majority-rule

122 consensus tree and posterior probabilities (PP). For the ML analyses, a rapid bootstrap analysis

123 was performed with a random seed, 1,000 alternative runs, and the same partition scheme as in

124 the Bayesian analysis. The model parameters for each partition of the dataset were optimized

125 using RAxML with the GTRCAT command. Trees were visualized in FigTree v1.4.3

126 (http://tree.bio.ed.ac.uk/software/figtree/). The ML bootstrap support values (BS) were labeled 
127 on the corresponding branches of the BI trees.

128 Estimation of divergence times

129 Divergence times were estimated using the ITS dataset and the BEAST v.2.4.3 package

130 (Bouckaert et al. 2014). The ITS dataset was partitioned into the ITS1, 5.8S and ITS2 partitions,

131 and nucleotide substitution models were unlinked across the three partitions. Models were

132 determined using jModelTest. The log normal relaxed clock model was used, and the clock

133 model was linked across partitions. The birth-death model was employed and was linked across

134 partitions. Two independent MCMCs were each run for 50,000,000 generations, and samples

135 were stored every 1,000 generations. The effective sample size (ESS) of each sampled parameter

136 and the convergence between runs were checked using Tracer v.1.6

137 (http://beast.bio.ed.ac.uk/Tracer). The ESSs of all parameters exceeded 200, and the two

138 independent runs were convergent. After removing a $25 \%$ burn-in from each run, the trees from

139 the two runs were combined by using LogCombiner (Bouckaert et al. 2014). The maximum

140 clade credibility tree was found and annotated using TreeAnnotator (Bouckaert et al., 2014), and

141 only the branches with a posterior probability of greater than 0.5 were annotated. The dated tree

142 was visualized in FigTree v.1.4.3. 
144 Lavin et al. (2005). In the matK phylogeny reported in Lavin et al. (2005), the essential Genistoid according to the ages of the equivalent nodes that were previously estimated by Lavin et al.

156 (2005).

\section{Results}



markers (matK, $r b c L, p s b A$-trnH and $\operatorname{trn} L-\operatorname{trn} F)$ were concatenated. Phylogenetic analyses were conducted on both the nuclear and four combined plastid data sets (Figs. 1-3: Fig.1 emphasized the position of Pickeringia; Figs. 2-3 intensified the sampling for Sophoreae). The models used in the Bayesian analyses were as follows: $m a t K: \mathrm{GTR}+\mathrm{G}$; $p s b A-t r n H: \mathrm{HKY}+\mathrm{G} ; r b c L: \mathrm{HKY}+\mathrm{I}+\mathrm{G}$; trnL-trnF: GTR+G; ITS1: GTR+G; 5.8S: K80+G; ITS2: GTR+G. The ITS and plastid tree topologies were distinct with regard to some key groups, thus we analyzed them separately. genera. According to the detailed trees (Figs. 2 \& 3), all genera of this tribe, except Pickeringia, belonged to the well supported core Genistoids $(\mathrm{PP}=1 / \mathrm{BS}=100 \%$ and $\mathrm{PP}=1 / \mathrm{BS}=94 \%$ in Figs. 2 and 3, respectively). Four genera, Anagyris, Baptisia, Piptanthus and Thermopsis, clustered into the "Thermopsoid clade" (1/100\% for ITS tree; $1 / 94 \%$ for plastid tree), within which Anagyris (1/100\% \& 1/99\%) and Baptisia (1/100\% \& 0.95/95\%) were shown to be monophyletic. The monophyly of Piptanthus was also strongly supported by the ITS tree (1/99\%). Ammopiptanthus, appearing to be a sister group of Salweenia (1/100\% in both trees), 
175 clade but nested in the Sophoroid clade $(0.99 / 83 \%$ \& $0.71 / 74 \%)$, which in turn formed a robustly

176 supported group (1/96\% \& $1 / 100 \%$ for the tribe Sophoreae; see Discussion) sister to the

177 Thermopsoid clade.

178 The sampled taxa from the tribes Crotalarieae, Genisteae and Podalyrieae formed a clade

179 (the PCG clade; 0.89/80\% \& 0.92/79\%), while Bolusanthus Harms and Dicraeopetalum Harms

180 clustered together (the BOD clade; $1 / 100 \%$ in both trees). These two clades occupied a different

181 position in relation to Sophoreae $(0.92 / 88 \%$ \& $0.99 / 56 \%)$.

183 Estimating divergence time

Phylogenetic dating was conducted based on the ITS dataset (Fig. 4). The estimated mean

ages of the relevant clades and the $95 \%$ posterior density intervals (in parentheses) are as follows:

Sophoroid plus Thermopsoid clade, 30.61 (22.91, 38.28) Ma for the Maackia plus its sister clade,

for Node III. 
191

192

193

194

195

196

197

198

\section{Discussion}

Phylogenetic position of Thermopsideae

Thermopsideae, the widely distributed legume tribe containing six genera, was proposed by Yakovlev (1972), and was accepted in most subsequent studies (Lock 2005; Polhill 1994; Turner 1981; Wang 2001; Wei et al. 2010; Wei 1998; Yakovlev 1972). Phylogenetic research has indicated that most genera of this tribe are members of the core Genistoids, which in turn belongs to the Genistoid clade in a broad sense (Cardoso et al. 2012b; Cardoso et al. 2016;

Cardoso et al. 2013; Crisp et al. 2000; Pennington et al. 2001; Peters et al. 2010; Wojciechowski 2003). However, the western North American endemic genus, Pickeringia, was an outlier from the core Genistoids (Fig. 1; see also Lavin et al. 2005; Wojciechowski 2013; Wojciechowski et al. 2004; Azani et al. 2017). Therefore, Lock (2005) suggested that this genus should be excluded from Thermopsideae. Our results confirm this exclusion (Fig. 1). Pickeringia $(x=7)$ also differs from other genera of Thermopsideae $(x=8)$ in basic chromosome number (Chen 1992; Goldblatt 1981; Pan \& Huang 1993) and the absence of quinolizidine alkaloids (see Turner 1981; Käss \& Wink 1994; Crisp et al. 2000; Doyle et al. 2000; Wink 2013). With the exclusion of Pickeringia, Cardoso et al. (2012b, 2013) proposed to merge 
207 Thermopsideae into Sophoreae sensu Cardoso, which is characterized by free stamens, to render

208 it monophyletic. Merging Thermopsideae into Sophoreae is verified by our results (Figs. 2 \& 3).

209 A more inclusive Sophoreae sensu Cardoso can serve to avoid taxonomic over-fragmentation of

210 the core Genistoids taxa and the establishments of new tribes based on many small clades. On

211 the other hand, the clade comprising Bolusanthus speciosus Harms and Dicraeopetalum

212 mahafaliense (M. Peltier) Yakovlev (the BOD clade), was included in Sophoreae by Cardoso et

213 al. (2013), but was weakly supported. Such a relationship is not validated by our ITS tree (Fig. 2;

214 it is also not supported by the likelihood bootstrap value of the plastid tree, see Fig. 3). The

215 newly circumscribed Sophoreae, equal to Sophoreae sensu Cardoso but with the exclusion of the

216 BOD clade, is further divided into the Thermopsoid clade and the Sophoroid clade (Figs. 2 \& 3).

217 Cardoso et al. (2013) elevated Ormosia from Sophoreae as a distinct tribe (Ormosieae), yet our

218 results do not confirm the affiliation of Clathrotropis with this tribe (Figs. 2 \& 3).

219 The core Genistoids is composed of three robust groups: Sophoreae, the BOD clade and the

220 PCG clade. Our ITS and plastid tree topologies are incongruent with regard to these clades.

221 Sophoreae forms a clade with the PCG clade in the ITS tree (Fig. 2), but the PCG clade is sister

222 to the BOD clade in the plastid tree (Fig. 3). Although not all of the support values are significant 
223 (BI posterior probability $>0.95$, ML bootstrap value $>70 \%$ ), the current case of topological

224 discordance is similar to Xu et al. (2012), García et al. (2014) and Duan et al. (2016), which

225 likely implied a chloroplast capture event in the origin of Sophoreae. Nevertheless, highly

226 supported phylogenetic trees based on multi-locus nuclear and plastid genes are required to

227 further verify this hypothesis.

228

229 Phylogeny of the Thermopsoid clade

230 The Thermopsoid clade includes four genera: Anagyris, Baptisia, Piptanthus and a

231 polyphyletic Thermopsis. The clade is divided into two well supported groups: the Eurasian

232 group and the American group (Figs. 2 \& 3).

233 The monophyletic Anagyris (also see Ortega-Olivencia 2009) is endemic to the

234 Mediterranean region, and belongs to the Eurasian group (Figs 2 \& 3). The Eurasian group also

235 includes the Hengduan-Himalaya-distributed genus Piptanthus, whose monophyly was accepted

236 by Wang et al. (2006) and supported by our ITS results (Fig. 2). Baptisia is restricted to North

237 America (central, northern and southern states of the U.S.A.) and is embedded within the

238 American Thermopsoid group. Our analyses yielded robust support for this genus, similar to 
239 Wang et al. (2006), Uysal et al. (2014) and Zhang et al. (2015a).

240 Previous studies (Uysal et al. 2014; Wang et al. 2006; Zhang et al. 2015a) and the present

241 results (Figs. 2 \& 3) indicate a polyphyletic Thermopsis, with its species being assigned into both

242 the Eurasian and the American groups. It is obvious that Thermopsis needs further taxonomic

243 revision. It is noteworthy that three Asian species, Thermopsis fabacea (Pall.) DC., T. chinensis

244 Benth. ex S. Moore and T. turcica Kit Tan, Vural \& Küçük., cluster with the American group,

245 making the biogeography of this genus an attractive topic for future research. In addition, our

246 trees failed to support the generic status of the monotypic Vuralia Uysal \& Ertuğrul (=

247 Thermopsis turcica), which was proposed by Uysal et al. (2014) mainly based on some unique

248 morphological characters such as a three-carpellate ovary and indehiscent fruit. 
255 Fisch. ex DC., Ammothamnus Bunge, Echinosophora Nakai and Euchresta Benn. Sophora is a

256 widely distributed genus, and has been revised by various taxonomists (Bao 2010; Heenan et al.

257 2004; Ma 1990; Ma 1994; Tsoong 1981a; Tsoong 1981b; Vasil'chenko 1945; Yakovlev 1996).

258 The phylogeny and circumscription of the genus are long-standing puzzles that require

259 considerable effort to solve.

260 The former Thermopsideae member, Ammopiptanthus, which is sister to Salweenia,

261 constitutes another entity in the Sophoroid clade (Figs. 2 \& 3). Traditionally, Ammopiptanthus

262 contains two species: A. mongolicus and A. nanus (Cheng 1959; Fu 1987; Li \& Yan 2011; Wei

263 1998; Yakovlev 1996;), while Wei \& Lock (2010) merged the latter species into the former. Our

264 results (Figs. $2 \& 3$ ) confirmed the specific status of $A$. nanus, which is confined to southwest

265 Xinjiang in China and eastern Kyrgyzstan, compared to a non-overlapping range of $A$.

266 mongolicus in northern Inner Mongolia, northern Gansu, eastern Xinjiang, China and southern

267 Mongolia (Fig. 5). Taxonomic separation of the two species is also supported by morphological

268 (Cheng 1959; Wei 1998), anatomical (Yuan \& Chen 1993), cytological (Chen 1992; Liu et al.

269 1996; Pan \& Huang 1993) and biochemical (Feng et al. 2011; Shi 2009; Wei et al. 2007; Wei \&

270 Shi 1995; Yin \& Zhang 2004) evidence. Recently, Lazkov (2006) described a new species in 
271 Kyrgyzstan: Ammopiptanthus kamelinii Lazkov. The type specimen is not significantly distinct

272 from $A$. nanus and the type locality overlapped with that of $A$. nanus, so we suspend the

273 recognition of $A$. kamelinii.

274 On the other hand, Salweenia was originally established as a monotypic genus in Sophoreae

275 and Yue et al. (2011) identified a second species of this genus based on morphological and

276 phylogenetic evidence. Both species are endemic to the Hengduan Mountains in southwest China.

277 Phylogenetic reconstruction based on the plastid $r b c L$ sequence showed that Salweenia was sister

to a Maackia-Sophora-Euchresta clade (Doyle et al. 1997). Its sistership with Ammopiptanthus is

279 firstly discovered herein, which is further explicated as follow.

The abovementioned Ammopiptanthus-Salweenia group has a disjunct distribution.

Ammopiptanthus is recorded from arid regions of northwest China, southern Mongolia and 
287 is a relic survivor of the Tertiary flora (Sun 2002a; Sun \& Li 2003; Wang 2001; Wang et al. 2006;

288 Zhang et al. 2015a). Yet these studies were conducted in the now outdated context of

289 Thermopsideae, rather than the more informative context of Sophoreae. Furthermore, few studies

290 have highlighted the sister relationship between Ammopiptanthus and Salweenia.

et al. (2015a), may be valid if judged by the unique habit in the northwest desert of China: it is

this similar habit further supports its sister relationship status with Ammopiptanthus. Due to the and uplifting of the QTP initiated the retreat of the Tethys (ca. 45-30 Ma; Harrison et al. 1992; 
303 forest temporarily remained (Teng et al. 1997; Chen et al. 1999; Shi et al. 1999; Li 2001; Zhang

304 \& Fang 2016). The common ancestor of Ammopiptanthus and Salweenia arose in the Tertiary

305 evergreen forest of ancient Central Asia (the north coast of the Tethys) before 26.96 Ma (Fig. 4:

306 Node I). During the expansion of the Central Asian evergreen forest, this common ancestor

307 probably dispersed southwards along new land that emerged from the Tethys (as in Sun 2002b).

308 The third rapid uplift of the QTP happened 7-8 Ma (Harrison et al. 1992; Liu et al. 2001;

309 Wang et al. 2008; Zheng \& Yao 2006) and was followed by a major raising of the northwest

310 QTP at ca. 4.5 Ma (Zheng et al. 2000), causing a cooler climate and aridification of the Asian

311 inland. The Tertiary forest gradually gave way to psychrophytic and xerophytic shrubs and herbs

312 (Sun 2002a; Meng et al. 2015). This dramatic environmental change possibly led to the

313 divergence between Ammopiptanthus and Salweenia (ca. $4.74 \mathrm{Ma}$, see Fig. 4: Node II). The

314 former, remained in the Asian interior, kept the evergreen shrubby habit, and acquired xeric

315 characters, such as the pubescent, coriaceous leaves, in the arid central Asian habitat; while the

316 latter retained more traits from Tertiary flora in the less disturbed and wetter region of the

317 Hengduan Mountains (Sun 2002a, b; Sun \& Li 2003).

318 The split of the two Ammopiptanthus species (2.04 Ma; see Fig. 4: Node III) is possibly a 
319 response to the last (fourth) rapid uprising of the QTP, when aridification of the Asian interior

320 intensified and the Loess Plateau formed, which potentially served as a geological barrier and

321 facilitated speciation (3.6-2.5 Ma; Chen et al. 1999; Li \& Fang 1999; Li 2001; Tang \& Liu 2001;

322 Zheng \& Yao 2006). This estimated age is slightly older than that proposed in Su et al. (2016),

323 who similarly suggested that the speciation of Ammopiptanthus was caused by climate oscillation

324 and range shifts. Ammopiptanthus nanus grows in a dryer habitat than that of $A$. mongolicus; the

325 former, therefore, possesses more xeric apomorphies such as shorter habit, usually 1-foliolate

326 leaves, conspicuous leaf venation, thicker root cortex, more complex karyotype and more

327 vulnerable phytocommunities (Cheng 1959; Pan \& Huang 1993; Wei 1998; Zhang et al. 2007).

328 Such disjunction resulting from the QTP uplift can be found in other Fabaceae species.

329 Examples are the infra-generic biogeography of some genera in the tribe Caraganeae (QTP-NW

330 China/C Asia disjunction; see Zhang et al. 2010; Zhang et al. 2015b; Zhang et al. 2015c) and the

331 inter-generic evolutionary history of Gueldenstaedtia and Tibetia (mesic E Asia-QTP disjunction;

332 see Xie et al., 2016). Our results may provide new insight into the evolutionary pattern of an

333 inter-generic QTP-Asian interior disjunctive distribution.

\section{Conclusion}


North America, its phylogeny has been controversial for decades. According to our results,

Pickeringia was excluded from Thermopsideae. The previous finding, that this tribe is part of an expanded Sophoreae, was confirmed herein. The re-delimited Sophoreae contained two clades: Thermopsoid and Sophoroid clade. Monophyly of Anagyris, Baptisia and Piptanthus were supported in the former clade. On the other hand, Ammopiptanthus, including A. mongolicus and

\section{Acknowledgments} providing the photograph in Fig. 5D. 


\section{References}

Akdeniz D, Ozmen A. 2011. Antimitotic effects of the biopesticide oxymatrine. Caryologia 64:117-120.

Azani N, Babineau M, Bailey CD, Banks H, Barbosa AR, Pinto RB, Boatwright JS, Borges LM, Brown GK, Bruneau A, Candido E, Cardoso D, Chung K-F, Clark RP, Conceicao AdS, Crisp M, Cubas P, Delgado-Salinas A, Dexter KG, Doyle JJ, Duminil J, Egan AN, de la Estrella M, Falcao MJ, Filatov DA, Fortuna-Perez AP, Fortunato RH, Gagnon E, Gasson P, Rando JG, Goulart de Azevedo Tozzi AM, Gunn B, Harris D, Haston E, Hawkins JA, Herendeen PS, Hughes CE, Iganci JRV, Javadi F, Kanu SA, Kazempour-Osaloo S, Kite GC, Klitgaard BB, Kochanovski FJ, Koenen EJM, Kovar L, Lavin M, le Roux M, Lewis GP, de Lima HC, LopezRoberts MC, Mackinder B, Maia VH, Malecot V, Mansano VF, Marazzi B, Mattapha S, Miller JT, Mitsuyuki C, Moura T, Murphy DJ, Nageswara-Rao M, Nevado B, Neves D, Ojeda DI, Pennington RT, Prado DE, Prenner G, de Queiroz LP, Ramos G, Ranzato Filardi FL, Ribeiro PG, Rico-Arce MdL, Sanderson MJ, Santos-Silva J, Sao-Mateus WMB, Silva MJS, Simon MF, Sinou C, Snak C, de Souza ER, Sprent J, Steele KP, Steier JE, Steeves R, Stirton CH, Tagane S, Torke BM, Toyama H, da Cruz DT, Vatanparast M, Wieringa JJ, Wink M, Wojciechowski MF, Yahara T, Yi T, and Zimmerman E. 2017. A new subfamily classification of the Leguminosae based on a taxonomically comprehensive phylogeny. Taxon 66:44-77.

Bao BJ, Vincent, MA. 2010. Sophora. In: Wu ZY, Hong, DY \& Raven PH, eds. Flora of China. 10. Beijing \& St. Louis: Science Press \& Missouri Botanical Garden Press. 85-93.

Bouckaert R, Heled J, Kühnert D, Vaughan T, Wu CH, Xie D, Suchard MA, Rambaut A, Drummond AJ. 2014. BEAST 2: a software platform for Bayesian evolutionary analysis. PLoS Comput Biol 10:e1003537.

Cardoso D, de Lima HC, Rodrigues RS, de Queiroz LP, Pennington RT, Lavin M. 2012a. The realignment of Acosmium sensu stricto with the Dalbergioid clade (Leguminosae: Papilionoideae) reveals a proneness for independent evolution of radial floral symmetry among early-branching papilionoid legumes. Taxon 61:1057-1073.

Cardoso D, De Queiroz LP, Pennington RT, De Lima HC, Fonty É, Wojciechowski MF, Lavin M. 2012b. Revisiting the phylogeny of papilionoid legumes: New insights from comprehensively sampled early-branching lineages. American Journal of Botany 99:1991-2013.

Cardoso D, Harris DJ, Wieringa JJ, São-Mateus WM, Batalha-Filho H, Torke BM, Prenner G, de Queiroz LP. 2016. A molecular-dated phylogeny and biogeography of the monotypic legume genus Haplormosia, a missing African branch of the otherwise American-Australian Brongniartieae clade. Molecular Phylogenetics and Evolution.

Cardoso D, Pennington R, De Queiroz L, Boatwright J, Van Wyk B-E, Wojciechowski M, Lavin M. 2013. Reconstructing the deep-branching relationships of the papilionoid 
legumes. South African Journal of Botany 89:58-75.

Chen CJ, Mendenhall MG, Turner BL. 1994. Taxonomy of Thermopsis (Fabaceae) in North America. Annals of the Missouri Botanical Garden:714-742.

Chen CJ, Zhu, XY, Yuan, YM. 1992. Cytological studies on the tribe Thermopsideae (Fabaceae) I: Report on karyotypes of eleven species of four genera. Cathaya 4:103-116.

Chen LX, Liu JP, Zhou XJ, Wang PX. 1999. Impact of uplift of Qinghai-Xizang Plateau and change of land-ocean distribution on climate over Asia. Quaternary Sciences 4:314-329.

Cheng SH. 1959. Ammopiptanthus Cheng f., a new genus of Leguminosae from central Asia. Botanicheskii Zhurnal 44:1381-1386.

Crepet WL, Herendeen PS. 1992. Papilionoid flowers from the early Eocene of southeastern North America. In: Herendeen P, Dilcher D, eds. Advances in legume systematics. 4. Kew, Richmond: Royal Botanic Gardens. 43-55.

Crisp M, Gilmore S, Van Wyk BE. 2000. Molecular phylogeny of the genistoid tribes of papilionoid legumes. In: Herendeen P, Bruneau A, eds. Advances in legume systematics. 9. Kew, Richmond: Royal Botanic Gardens. 249-276.

Czefranova Z. 1970. Series novae generis Thermopsis R.Br. Novitates Systematicae Plantarum Vascularium 7:213-216.

Darriba D, Taboada GL, Doallo R, Posada D. 2012. jModelTest 2: more models, new heuristics and parallel computing. Nature methods 9:772-772.

Doyle J, Chappill J, Bailey C, Kajita T. 2000. Towards a comprehensive phylogeny of legumes: evidence from $r b c L$ sequences and non-molecular data. In: Herendeen P, Bruneau A, eds. Advances in Leguminosae systematics. 9. Kew, Richmond: Royal Botanic Gardens, 1-20.

Doyle JJ, Doyle JL, Ballenger JA, Dickson EE, Kajita T, Ohashi H. 1997. A phylogeny of the chloroplast gene $r b c L$ in the Leguminosae: Taxonomic correlations and insights into the evolution of nodulation. American Journal of Botany 84: 541-554.

Duan L, Yang X, Liu PL, Johnson G, Wen J, Chang ZY. 2016. A molecular phylogeny of Caraganeae (Leguminosae, Papilionoideae) reveals insights into new generic and infrageneric delimitations. PhytoKeys 70:111-137.

Edgar RC. 2004. MUSCLE: multiple sequence alignment with high accuracy and high throughput. Nucleic acids research 32:1792-1797.

Feng WJ, Ou YF, Su YL, Li J, Ji TF. 2011. Chemical constituents of Ammopiptanthus mongolicus. China journal of Chinese materia medica 36:1040-1042.

Fu KT. 1987. Ammopiptanthus and Thermopsis. In: Liou YX, ed. Flora in Desertis Reipublicae Populorum Sinarum. 2. Beijing: Science Press, 230-232.

García N, Meerow AW, Soltis DE, Soltis PS. 2014. Testing deep reticulate evolution in Amaryllidaceae tribe Hippeastreae (Asparagales) with ITS and chloroplast sequence data. Systematic Botany 39:75-89.

Goldblatt P. 1981. Cytology and the phylogeny of Leguminosae. In: Polhill RM, Raven PH, eds. Advances in legume systematics. 1. Kew, Richmond: Royal Botanic Gardens. 427-463.

Harrison TM, Copeland P. 1992. Raising tibet. Science 255:1663. 
Heenan PB, Dawson MI, Wagstaff SJ. 2004. The relationship of Sophora sect. Edwardsia (Fabaceae) to Sophora tomentosa, the type species of the genus Sophora, observed from DNA sequence data and morphological characters. Botanical Journal of the Linnean Society 146:439-446.

Herendeen PS, Dilcher DL. 1990. Diplotropis (Leguminosae, Papilionoideae) from the Middle Eocene of southeastern North America. Systematic Botany 15:526-533.Kajita T, Ohashi H, Tateishi Y, Bailey CD, Doyle JJ. 2001. $r b c L$ and legume phylogeny, with particular reference to Phaseoleae, Millettieae and allies. Systematic Botany 26:515-536.

Käss E, Wink M. 1994. Molecular phylogeny of the papilionoideae (family Leguminosae) - $r b c l$ gene-sequences versus chemical taxonomy. Botanica Acta 108:149-162.

Käss E, Wink M. 1997. Phylogenetic relationships in the papilionoideae (family Leguminosae) based on nucleotide sequences of cpDNA ( $r b c L)$ and ncDNA (ITS 1 and 2). Molecular Phylogenetics and Evolution 8:65-88.

Kearse M, Moir R, Wilson A, Stones-Havas S, Cheung M, Sturrock S, Buxton S, Cooper A, Markowitz S, Duran C. 2012. Geneious Basic: an integrated and extendable desktop software platform for the organization and analysis of sequence data. Bioinformatics 28:1647-1649.

Larisey MM. 1940a. A monograph of the genus Baptisia. Annals of the Missouri Botanical Garden 27:119-244.

Larisey MM. 1940b. A revision of the North American species of the genus Thermopsis. Annals of the Missouri Botanical Garden 27:245-258.

Lavin M, Herendeen PS, Wojciechowski MF. 2005. Evolutionary rates analysis of Leguminosae implicates a rapid diversification of lineages during the Tertiary. Systematic Biology 54:575-594.

Lazkov G. 2006. Generis Ammopiptanthus S.H.Cheng (Fabaceae) species nova e Kyrgyzstania. Novitates Systematicae Plantarum Vascularium 38:134-138.

Lee WK, Tokuoka T, Heo K. 2004. Molecular evidence for the inclusion of the Korean endemic genus "Echinosophora" in Sophora (Fabaceae) and embryological features of the genus. Journal of plant research 117:209-219.

Li J, Fang X. 1999. Uplift of the Tibetan Plateau and environmental changes. Chinese Science Bulletin 44:2117-2124.

Li JJ, Fang XM, Pan BT, Zhao ZJ, Song YG. 2001. Late Cenozoic intensive uplift of QinghaiXizang Plateau and its impacts on environments in surrounding area. Quaternary Sciences 21:381-391.

Li PQ, Ni CC. 1982. The formation and differentiation of the Leguminosae flora in Xizang (Tibet). Acta Phytotaxonomica Sinica 20:142-156.

Li XY, Yan P. 2011. Leguminosae. In: Sheng GM, ed. Flora Xinjiangensis. 3. Xinjiang: Xinjiang Science \& Technology Publishing House, 11-12.

Liu S, Chi X, Li C, Yang R. 2001. The summarizing for the forming and uplifted mechanism of Qinghai-Tibet Plateau. World Geology 20:105-112.

Liu YH, Wang SM, Wang HS. 1996. A study on the chromosomal geography of 
Ammopiptanthus genus. Geographical Research 15(4): 40-47.

Lock J. 2005. Thermopsideae. In: Lewis G, Schrire B, Mackinder B, Lock M, eds. Legumes of the world. Kew, Richmond: Royal Botanic Gardens, 263-265.

Ma CY. 1990. Review of the classifical system on the genus Sophora. Bulletin of Botanical Research 10:77-86.

Ma CY. 1994. Sophora. In: Wei Z, ed. Flora Reipublicae Popularis Sinicae. 40. Beijing: Science Press, 64-95.

Meng HH, Gao XY, Huang JF, Zhang ML. 2015. Plant phylogeography in arid Northwest China: retrospectives and perspectives. Journal of Systematics and Evolution 53(1): 3346.

Meng HH, Su T, Gao XY, Li J, Jiang XL, Sun H, Zhou ZK. 2017. Warm-cold colonization: response of oaks to uplift of the Himalaya-Hengduan Mountains. Molecular Ecology 2017.

Ortega-Olivencia A. 2009. Systematics and evolutionary history of the circum-Mediterranean genus Anagyris L.(Fabaceae) based on morphological and molecular data. Taxon 58:1290-1306.

Pan BR, Huang SP. 1993. A cytological studies of genus Ammopiptanthus. Acta Botanica Sinica 35.

Peng ZX, Yuan YM. 1992. Systematic revision on Thermopsideae (Leguminosae) of China. Acta Botanica Boreali-Occidentalia Sinica 12:158-166.

Pennington RT, Lavin M, Ireland H, Klitgaard B, Preston J, Hu JM. 2001. Phylogenetic relationships of basal papilionoid legumes based upon sequences of the chloroplast trnL intron. Systematic Botany 26:537-556.

Peters WS, Haffer D, Hanakam CB, van Bel AJ, Knoblauch M. 2010. Legume phylogeny and the evolution of a unique contractile apparatus that regulates phloem transport. American Journal of Botany 97:797-808.

Polhill RM. 1994. Classification of the Leguminosae. In: Southon IW, Bisby FA, Buckingham J, Harborne JB, eds. Phytochemical dictionary of the Leguminosae. London: Chapman \& Hall. XXXV-LVII.

Ronquist F, Huelsenbeck JP. 2003. MrBayes 3: Bayesian phylogenetic inference under mixed models. Bioinformatics 19:1572-1574.

Sa R. 1999. Systematics of Thermopsis (Leguminosae). Ph.D. Thesis. Chinese Academy of Sciences.

Sa R, Sudebilige, Chen JR. 2000. Epidermal characters of leaves in Thermopsis and their biolocal significances. Acta Agrestia Sinica 8:66-76.

Shi W, Pan BR, Zhang Q. 2009. Comparison of element contents in habitat soil and plant leaves of Ammopiptanthus nanus and A. mongolicus. Chinese Journal of Applied and Environmental Biology 15:660-665.

Shi Y, Li J, Li B. 1999. Uplift of the Qinghai-Xizang (Tibetan) plateau and east Asia environmental change during late Cenozoic. Acta Geographica Sinica-Chinese Edition 
514

515

516

517

518

519

520

521

522

523

524

525

526

527

528

529

530

531

532

533

534

535

536

537

538

539

540

541

542

543

544

545

546

547

548

549

550

551

552

553

554

54:20-28.

Stamatakis A. 2014. RAxML version 8: a tool for phylogenetic analysis and post-analysis of large phylogenies. Bioinformatics 30:1312-1313.

Su Z, Pan B, Zhang M, Shi W. 2016. Conservation genetics and geographic patterns of genetic variation of endangered shrub Ammopiptanthus (Fabaceae) in northwestern China. Conservation Genetics 17:485-496.

Sun H. 2002a. Tethys retreat and Himalayas-Hengduanshan Mountains uplift and their significance on the origin and development of the Sino-Himalayan elements and alpine flora. Acta Botanica Yunnanica 24:273-288.

Sun H. 2002b. Evolution of arctic-tertiary flora in Himalayan-Hengduan Mountains. Acta Botanica Yunnanica 24:671-688.

Sun H, Li Z. 2003. Qinghai-Tibet Plateau uplift and its impact on Tethys flora. Advances in Earth Science 18:852-862.

Tang M, Liu Y. 2001. On causes and environmental consequences of the uplift of QinghaiXizang Plateau. Quaternary Sciences 21:500-507.

Teng JW, ZHang ZJ, Zhang BM, Zhang H. 1997. Environmental change and the uplift of Tibetan Plateau. Earth Science Frontiers 4:247-254.

Tsoong PC, Ma CY. 1981a. A study on the genus Sophora Linn. Acta Phytotaxonomica Sinica 19:1-22.

Tsoong PC, Ma CY. 1981b. A study on the genus Sophora Linn. (Cont.). Acta Phytotaxonomica Sinica 19:143-167.

Turner BL. 1980. Revision of The Genus Piptanthus (Fabaceae, Thermopsideae). Brittonia 32:281-285.

Turner BL. 1981. Thermopsodeae. In: Polhill RM, Raven PH, eds. Advances in Legume Systematics. 1. Kew, Richmond: Royal Botanic Garden. 403-407.

Turner BL. 2006. Overview of the genus Baptisia (Leguminosae). Phytologia 88:253-268.

Uysal T, Ertuğrul K, Bozkurt M. 2014. A new genus segregated from Thermopsis (Fabaceae: Papilionoideae): Vuralia. Plant Systematics and Evolution 300:1627-1637.

Vasil'chenko IT. 1945. Sophora. In: Komarov VL, ed. Flora of the USSR. 11. Leningrad: Izdatel'stvo Akademii Nauk SSSR. 20-24.

Wang C, Zhao X, Liu Z, Lippert PC, Graham SA, Coe RS, Yi H, Zhu L, Liu S, Li Y. 2008. Constraints on the early uplift history of the Tibetan Plateau. Proceedings of the National Academy of Sciences 105:4987-4992.

Wang H. 2001. A preliminary study on phytogeography of the tribe Thermopsideae (Papilionaceae). Acta Botanica Yunnanica 23:17-28.

Wang HC, Sun H, Compton JA, Yang JB. 2006. A phylogeny of Thermopsideae (Leguminosae : Papilionoideae) inferred from nuclear ribosomal internal transcribed spacer (ITS) sequences. Botanical Journal of the Linnean Society 151:365-373.

Wang Y, Jiao P, Li B, Liu C. 2010. Tissue Culture and Regeneration of Ammopiptanthus nanus (M.Pop.) Cheng f. Plant Physiology Communications 46:375-376.

Wei H, Wu P, Ge X, Liu M, Wei X. 2007. Chemical constituents of the seeds of 
555

556

557

558

559

560

561

562

563

564

565

566

567

568

569

570

571

572

573

574

575

576

577

578

579

580

581

582

583

584

585

586

587

588

589

590

591

592

593

594

595

Ammopiptanthus (Leguminosae) and their systematic and ecological significance. Biochemical Systematics and Ecology 35:274-280.

Wei KH, Gao SL, Huang HP. 2010. Tissue culture and generation of autotetraploid

Wei SQ. 1998. Thermopsideae. In: Cui HB, ed. Flora Reipublicae Popularis Sinicae. 42(2). Beijing: Science Press. 88-411.

Wei Y, Shi QH. 1995. Spectrum analysis on the esterase isozymes of Ammopiptanthus. Arid Zone Research 12:36, 53-54.

Wei Z, Lock JM. 2010. Fabaceae Tribe Thermopsideae. In: Wu ZY, Hong, DY, Raven PH, ed. Flora of China. 10. Beijing \& St. Louis: Science Press \& Missouri Botanical Garden Press. 100-104.

Wink M, Mohamed G. 2003. Evolution of chemical defense traits in the Leguminosae: mapping of distribution patterns of secondary metabolites on a molecular phylogeny inferred from nucleotide sequences of the $r b c L$ gene. Biochemical Systematics and Ecology 31:897-917.

Wink M. 2013. Evolution of secondary metabolites in legumes (Fabaceae). South African Journal of Botany 89:164-175.

Wojciechowski MF. 2003. Reconstructing the phylogeny of legumes (Leguminosae): an early 21 st century perspective. In: Klitgaard BB, Bruneau A, eds. Advances in legume systematics. 10. Kew, Richmond: Royal Botanic Garden. 5-35.

Wojciechowski MF. 2013. The Origin and Phylogenetic Relationships of the Californian Chaparral 'Paleoendemic' Pickeringia (Leguminosae). Systematic Botany 38:132-142.

Wojciechowski MF, Lavin M, Sanderson MJ. 2004. A phylogeny of legumes (Leguminosae) based on analyses of the plastid matK gene resolves many well-supported subclades within the family. American Journal of Botany 91(11): 1846-1862.

Xie YP, Meng Y, Sun H, Nie ZL. 2016. Molecular phylogeny of Gueldenstaedtia and Tibetia (Fabaceae) and their biogeographic differentiation within Eastern Asia. PloS one 11:e0162982.

Xu B, Wu N, Gao XF, Zhang LB. 2012. Analysis of DNA sequences of six chloroplast and nuclear genes suggests incongruence, introgression and incomplete lineage sorting in the evolution of Lespedeza (Fabaceae). Molecular Phylogenetics and Evolution 62:346-358.

Yakovlev GP. 1972. A contribution to the system of the order Fabales Nakai (Leguminales Jones). Botanicheskii Zhurnal 57.

Yakovlev GP. 1988. Thermopsis. In: Yakovlev GP, ed. Plants of Central Asia. 8a. Enfield \& Plymouth: Science Publishers, Inc. 12-17.

Yakovlev GP. 1996. Thermopsideae. In: Yakovlev GP, Sytin AK, Roskov YR, eds. Legumes of Northern Eurasia: a checklist. Kew, Richmond: Royal Botanic Gardens. 461-465.

Yin LK, Zhang J. 2004. Change of the protein amino acid content in Ammopiptanthus Cheng f. under the different habitats. Arid Zone Research 21:269-274.

Yuan YM, Chen JR. 1993. Anatomical evidence for phylogeny of the tribe Thermopsideae (Fabaceae). Journal of Lanzhou University Natural Sciences:97-104.

Yue XK, Yue JP, Yang LE, Li ZM, Sun H. 2011. Systematics of the genus Salweenia 
596

597

598

599

600

601

602

603

604

605

606

607

608

609

610

611

612

613

614

615

616

617
(Leguminosae) from Southwest China with discovery of a second species. Taxon 60:1366-1374.

Zhang J, Liao K, Li D, Yan Z, Zhang J. 2010. Distribution pattern and characteristics of Ammopiptanthus mongolicus in several different habitat conditions. Journal of Arid Land Resources and Environment 24:151-154.

Zhang LS, Fang XQ. 2016. Palaeogeography of China: formation of natural environment in China. Beijing: Science Press.137-206.

Zhang ML, Wen ZB, Fritsch PW, Sanderson SC. 2015b. Spatiotemporal evolution of Calophaca (Fabaceae) reveals multiple dispersals in central Asian mountains. PloS one 10:e0123228.

Zhang ML, Wen ZB, Hao XL, Byalt VV, Sukhorukov AP, Sanderson SC. 2015c. Taxonomy, phylogenetics and biogeography of Chesneya (Fabaceae), evidenced from data of three sequences, ITS, trnS-trnG and rbcL. Biochemical Systematics and Ecology 63:80-89.

Zhang ML, Huang JF, Sanderson SC, Yan P, Wu YH, Pan BR. 2015a. Molecular biogeography of tribe Thermopsideae (Leguminosae): a Madrean-Tethyan disjunction pattern with an African origin of core genistoides. BioMed research international 2015.

Zhang Q, Pan BR, Zhang YZ, Duan SM. 2007. Analysis on the characteristics of communities of Ammopiptanthus nanus and A. mongolicus. Arid Zone Research 24:487-494.

Zheng D, Yao TD. 2006. Uplifting of tibetan plateau with its environmental effects. Advances in Earth Science 21:451-458.

Zheng H, Powell CM, An Z, Zhou J, Dong G. 2000. Pliocene uplift of the northern Tibetan Plateau. Geology 28:715-718. 
619 Figure 1. Bayesian tree of the concatenated nuclear ITS (A) and the concatenated plastid data of

$620 m a t K, r b c L, t r n L-t r n F$ and $p s b A$-trnH sequences (B) for Themopsideae and related genera.

621 Bayesian posterior probabilities and maximum likelihood bootstrap values are given above the

622 branches.

623

624 Figure 2. Bayesian tree of the concatenated nuclear ITS data, showing Sophoreae and its allies.

625 Bayesian posterior probabilities and maximum likelihood bootstrap values are given above the

626 branches.

627

628

Figure 3. Bayesian tree of the concatenated plastid data of $m a t K, r b c L, \operatorname{trn} L-\operatorname{trn} F$ and $p s b A-\operatorname{trn} H$

629 sequences, showing Sophoreae and its allies. Bayesian posterior probabilities and maximum likelihood bootstrap values are given above the branches.

631

Figure 4. Divergence times for Sophoreae/Themopsideae genera estimated by using BEAST based on the ITS dataset. Calibration points are marked by A-D. Node labels and bars represent 
635 III represent the divergence ages of 26.96 Ma, 4.74 Ma and 2.04 Ma, respectively.

636 Figure 5. Distribution (A) and representative plants of Ammopiptanthus (B \& C) and Salweenia

637 (D). A: red - Ammopiptanthus (I: distribution of A. mongolicus; II: distribution of A. nanus),

638 green - Salweenia; B: Ammopiptanthus mongolicus; C: Ammopiptanthus nanus; D: Salweenia

639 wardii. 


\section{Table $\mathbf{1}$ (on next page)}

Table 1. Taxa names, sources and GenBank accession numbers of DNA sequences

New sequences generated in this study are indicated by an asterisk $(*)$, Missing sequences are indicated by a dash (-). 
Table 1. Taxa names, sources and GenBank accession numbers of DNA sequences. New sequences generated in this study are indicated by an asterisk $(*)$.

2 Missing sequences are indicated by a dash (-).

\begin{tabular}{|c|c|c|c|c|c|c|}
\hline \multirow{3}{*}{ Species Pop. } & \multicolumn{5}{|c|}{ GenBank Accession Number } & \multirow{3}{*}{ Sources } \\
\hline & & & & $p s b A-$ & & \\
\hline & ITS & $r b c L$ & matK & $\operatorname{trn} H$ & $\operatorname{trn} L-\operatorname{trn} F$ & \\
\hline Ammopiptanthus nanus & KP636563 & - & JQ820170 & KP636577 & KP636626 & \\
\hline Ammopiptanthus nanus A & KU178932 & - & - & KU178934 & KU178937 & $39.66^{\circ} \mathrm{N}, 74.75^{\circ} \mathrm{E}, 2290 \mathrm{~m}$ \\
\hline Ammopiptanthus nanus B & KU178932 & - & - & KU178935 & KU178937 & $39.49^{\circ} \mathrm{N}, 74.88^{\circ} \mathrm{E}, 2512 \mathrm{~m}$ \\
\hline Ammopiptanthus nanus $\mathrm{C}$ & KU178932 & - & - & KU178934 & KU178937 & $39.76^{\circ} \mathrm{N}, 76.39^{\circ} \mathrm{E}, 2350 \mathrm{~m}$ \\
\hline Ammopiptanthus mongolicus & KP636562 & - & JQ820168 & KP636576 & KP636624 & \\
\hline Ammopiptanthus mongolicus D & KU178933 & - & - & KU178936 & KU178938 & $41.63^{\circ} \mathrm{N}, 103.22^{\circ} \mathrm{E}, 1010 \mathrm{~m}$ \\
\hline Ammopiptanthus mongolicus E & KU178933 & - & - & KU178936 & KU178939 & $40.49^{\circ} \mathrm{N}, 106.86^{\circ} \mathrm{E}, 1039 \mathrm{~m}$ \\
\hline Ammopiptanthus mongolicus $\mathrm{F}$ & KU178933 & - & - & KU178936 & KU178940 & $38.98^{\circ} \mathrm{N}, 105.87^{\circ} \mathrm{E}, 1762 \mathrm{~m}$ \\
\hline Ammopiptanthus mongolicus $\mathrm{G}$ & KU178933 & - & - & KU178936 & KU178941 & $37.99^{\circ} \mathrm{N}, 105.25^{\circ} \mathrm{E}, 1323 \mathrm{~m}$ \\
\hline Ammopiptanthus mongolicus $\mathrm{H}$ & KU178933 & - & - & KU178936 & KU178940 & $37.93^{\circ} \mathrm{N}, 105.26^{\circ} \mathrm{E}, 1355 \mathrm{~m}$ \\
\hline Ammopiptanthus mongolicus 270 & KU178933 & - & - & * & * & $\begin{array}{l}\text { China: Turpan, Turpan Eremophytes Botanic } \\
\text { Garden, Pan b.r. (TURP) }\end{array}$ \\
\hline Ammodendron conollyi & EF457705 & - & - & - & - & \\
\hline Ammodendron argenteum & - & - & AY386957 & - & - & \\
\hline Ammothamnus lehmannii & EF457706 & - & - & - & - & \\
\hline Anagyris foetida & AY091571 & $\mathrm{Z} 70122$ & KP230735 & - & FJ499429 & \\
\hline Anagyris latifolia & FJ482248 & - & - & - & FJ499419 & \\
\hline Anarthrophyllum desideratum & - & - & AY386923 & - & - & \\
\hline Anarthrophyllum rigidum & FJ839488 & - & - & - & FJ839594 & \\
\hline Baptisia alba & AY773348 & KP126860 & KP126860 & - & - & \\
\hline Baptisia cinerea & AY773350 & - & - & - & - & \\
\hline Baptisia tinctoria & $\begin{array}{l}\text { Z72314 \& } \\
\text { Z72315 }\end{array}$ & Z70120 & - & - & AJ890964 & \\
\hline
\end{tabular}




\begin{tabular}{|c|c|c|c|c|c|c|}
\hline Baptisia sphaerocarpa & AY773351 & - & - & - & - & \\
\hline Baptisia australis & AY091572 & KF613006 & AY386900 & - & FJ499421 & \\
\hline Baptisia bracteata & AY773349 & KP126854 & KP126854 & - & - & \\
\hline Bolusanthus speciosus & EF457708 & U74243 & AF142685 & - & AF310994 & \\
\hline Bowdichia nitida & JX124478 & - & JX124419 & - & JX124432 & \\
\hline Cadia purpurea & KF850559 & U74192 & JX295932 & - & AF309863 & \\
\hline Castanospermum australe & * & - & * & * & $*$ & USA: Sri Lanka, kandy, Rudd v.e.3339 (US) \\
\hline Calpurnia aurea & CAU59887 & U74239 & AY386951 & - & AF310993 & \\
\hline Clathrotropis brachypetala & EF457714 & - & - & - & AF309827 & \\
\hline Clathrotropis macrocarpa & - & - & JX295930 & - & JX275957 & \\
\hline Crotalaria incana & JQ067262 & JQ591662 & GQ246141 & JQ067481 & KP691137 & \\
\hline Cyclolobium nutans & AF467041 & - & AF142686 & - & AF309857 & \\
\hline Cytisus scoparius & AF351120 & KM360746 & AY386902 & - & $\begin{array}{l}\text { KJ746350 \& } \\
\text { AF352216 }\end{array}$ & \\
\hline Dicraeopetalum mahafaliense & EF457716 & - & - & - & - & \\
\hline Dicraeopetalum stipulare & - & - & GQ246142 & - & AF310995 & \\
\hline Diplotropis purpurea & JX124507 & JQ625878 & JX124418 & GQ428691 & JX124441 & \\
\hline Echinosophora koreensis & - & AB127036 & - & - & AB127028 & \\
\hline Euchresta formosana & - & AB127039 & - & - & AB127031 & \\
\hline Euchresta japonica & - & AB127040 & - & - & AB127032 & \\
\hline Genista monspessulana & JF338307 & KM360800 & AY386862 & - & $\begin{array}{l}\text { JF338219 \& } \\
\text { JF338559 }\end{array}$ & \\
\hline Guianodendron praeclarum & JX124489 & - & JX124403 & - & JX124443 & \\
\hline Lupinus argenteus & AY338929 & - & AY386956 & - & $\begin{array}{l}\text { AY618502 } \\
\text { \&AF538706 }\end{array}$ & \\
\hline
\end{tabular}




\begin{tabular}{|c|c|c|c|c|c|c|}
\hline Maackia amurensis & * & Z70137 & AY386944 & * & * & China: Jilin, Fusong, Sun s.n. (NENU) \\
\hline Maackia amurensis subsp. buergeri & - & AB127041 & - & - & - & \\
\hline Maackia chinensis & EF457721 & - & - & - & - & \\
\hline Maackia floribunda & - & $\mathrm{AB} 127042$ & - & - & AB127034 & \\
\hline Maackia tashiroi & - & $\mathrm{AB} 127043$ & - & - & $\mathrm{AB} 127035$ & \\
\hline Ormosia amazonica & EF457724 & GQ981820 & - & GQ982307 & AF309484 & \\
\hline Ormosia fordiana & KP092737 & КР094453 & KР093527 & КР095377 & - & \\
\hline Ormosia coccinea & - & JQ625915 & GQ982055 & GQ982308 & - & \\
\hline Ormosia costulata & - & - & JX295887 & - & JX275917 & \\
\hline Pickeringia montana & $*$ & - & $*$ & * & * & Mexico: Tecate, Moran r. 13982 (US) \\
\hline Ormosia arborea & - & KF981227 & JX295939 & - & - & \\
\hline Piptanthus laburnifolius & KP636565 & - & - & KP636579 & KР636630 & \\
\hline Piptanthus nepalensis & AF215922 & Z70123 & AY386924 & - & - & \\
\hline Piptanthus nepalensis 1 & FJ482250 & - & - & KР636581 & KP636631 & \\
\hline Piptanthus tomentosus & AY091570 & - & - & - & - & \\
\hline Piptanthus concolor & KР636564 & - & - & KP636578 & КР636629 & \\
\hline Piptanthus leiocarpus & AY091569 & - & - & KР636580 & - & \\
\hline Piptanthus leiocarpus & KP636566 & - & - & - & - & \\
\hline Poecilanthe itapuana & KJ028462 & AB045818 & KJ028458 & - & - & \\
\hline Poecilanthe parviflora & KJ028463 & - & KJ028459 & - & AF208897 & \\
\hline Salweenia wardii & * & U74251 & - & JF725689 & JF725659 & $\begin{array}{l}\text { China: Tibet, Qamdo, Chang et al. QZ-491 } \\
\text { (WUK) }\end{array}$ \\
\hline Salweenia bouffordiana & - & - & - & JF725692 & JF725662 & \\
\hline Sophora davidii & AY773352 & Z70138 & AY386958 & JF725695 & JF725665 & \\
\hline
\end{tabular}




\begin{tabular}{|c|c|c|c|c|c|}
\hline Sophora flavescens & FJ528290 & Z70139 & HM049520 & JF725696 & JF725666 \\
\hline Sophora velutina & FN813569 & - & - & - & AF309828 \\
\hline \multirow[t]{2}{*}{ Sophora jaubertii } & Z72342 \& & & & & \\
\hline & Z72343 & Z70140 & - & - & - \\
\hline \multirow[t]{2}{*}{ Sophora macrocarpa } & Z95563 \& & & & & \\
\hline & Z95577 & AY725479 & JQ619975 & - & - \\
\hline Sophora inhambanensis & FN813570 & KM894237 & KM896910 & - & - \\
\hline Sophora tomentosa & HQ207666 & AB127038 & - & JX495463 & $\mathrm{AB} 127030$ \\
\hline Sophora tetraphylla & AJ310734 & - & - & - & - \\
\hline Sophora howinsula & AY046514 & - & - & - & - \\
\hline Sophora microphylla & AY056075 & AY725480 & JQ619976 & GQ248391 & - \\
\hline Sophora prostrata & AY056077 & - & - & - & - \\
\hline Sophora raivavaeensis & AY056080 & - & - & - & - \\
\hline Sophora toromiro & AY056079 & GQ248696 & GQ248201 & GQ248392 & - \\
\hline Sophora viciifolia & - & KP088855 & KP089313 & - & - \\
\hline \multirow[t]{2}{*}{ Spartium junceum } & DQ524327 & KM360993 & AY386901 & HE966833 & JF338264 \& \\
\hline & & & & & JF338600 \\
\hline Thermopsis inflata & AF123451 & - & - & - & - \\
\hline Thermopsis inflata 1 & - & - & - & KP636586 & KP636638 \\
\hline Thermopsis inflata 2 & - & - & - & - & KР636639 \\
\hline Thermopsis inflata 3 & - & - & - & KP636587 & KP636640 \\
\hline Thermopsis smithiana & KP636573 & - & - & KP636597 & KP636650 \\
\hline Thermopsis turkestanica & KP636574 & - & - & KP636598 & KP636651 \\
\hline Thermopsis mongolica & KP636570 & - & - & KP636594 & KP636647 \\
\hline Thermopsis alpina & KP636567 & - & JQ669594 & KP636582 & KP636632 \\
\hline
\end{tabular}


Thermopsis alpina 1

Thermopsis alpina 2

Thermopsis alpina 3

Thermopsis alpina 4

Thermopsis lanceolata

Thermopsis lanceolata 1

Thermopsis przewalskii

Thermopsis schischkinii

Thermopsis yushuensis

Thermopsis barbata

Thermopsis licentiana

Thermopsis licentiana 1

Thermopsis licentiana 3

Thermopsis licentiana 4

Thermopsis turcica

Thermopsis chinensis

Thermopsis macrophylla

Thermopsis divaricarpa

Thermopsis villosa

Thermopsis rhombifolia

Thermopsis rhombifolia var. ovata

Thermopsis fabacea

Thermopsis kaxgarica

Thermopsis montana

\begin{tabular}{|c|c|c|c|c|}
\hline AF123447 & - & - & -- & KP636633 \\
\hline - & - & - & KP636583 & KP636634 \\
\hline - & - & - & KР636584 & KР636635 \\
\hline - & - & - & KP636585 & KР636636 \\
\hline AF123448 & - & JQ669595 & KР636589 & KP636642 \\
\hline - & - & - & КР636590 & КР636643 \\
\hline KP636571 & - & - & - & KP636648 \\
\hline КР636572 & - & - & КР636596 & КР636649 \\
\hline KP636575 & - & - & KP636599 & KP636652 \\
\hline KP636568 & - & - & - & KP636637 \\
\hline КР636569 & - & - & - & - \\
\hline - & - & - & КР636591 & КР636644 \\
\hline - & - & - & KP636592 & KР636645 \\
\hline - & - & - & KР636593 & KР636646 \\
\hline JQ425645 & KT175217 & KT175216 & KT175218 & - \\
\hline AF123443 & - & - & GU396777 & - \\
\hline AF123450 & - & - & - & - \\
\hline AY091575 & - & - & - & - \\
\hline AY773355 & - & - & - & AF311384 \\
\hline KР861904 & JX848468 & AY386866 & KP861905 & AY618487 \\
\hline AF007468 & - & - & - & - \\
\hline AY091573 & Z70121 & - & - & - \\
\hline - & - & - & KР636588 & KР636641 \\
\hline AY091574 & - & - & - & AF385411 \& \\
\hline
\end{tabular}


Ulex europaeus

AY263686

KM361025

JQ669586

AF385937

AF385427

\&AY264062

3 *I will added the Genebank number after accepted 
Figure 1

Figure 1. Bayesian tree of the concatenated nuclear ITS (A) and the concatenated plastid data of matK, rbcL, trnL-trnF and psbA-trnH sequences (B) for Themopsideae and related genera.

Bayesian posterior probabilities and maximum likelihood bootstrap values are given above the branches.

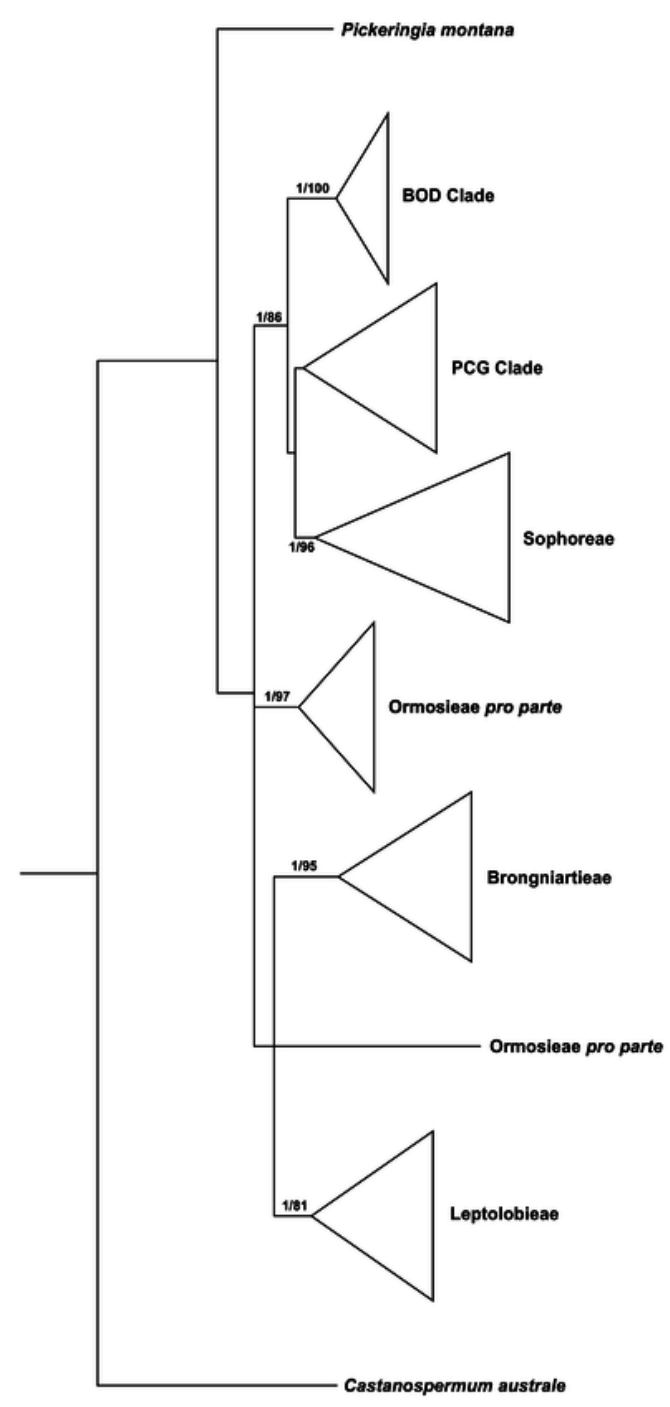

A

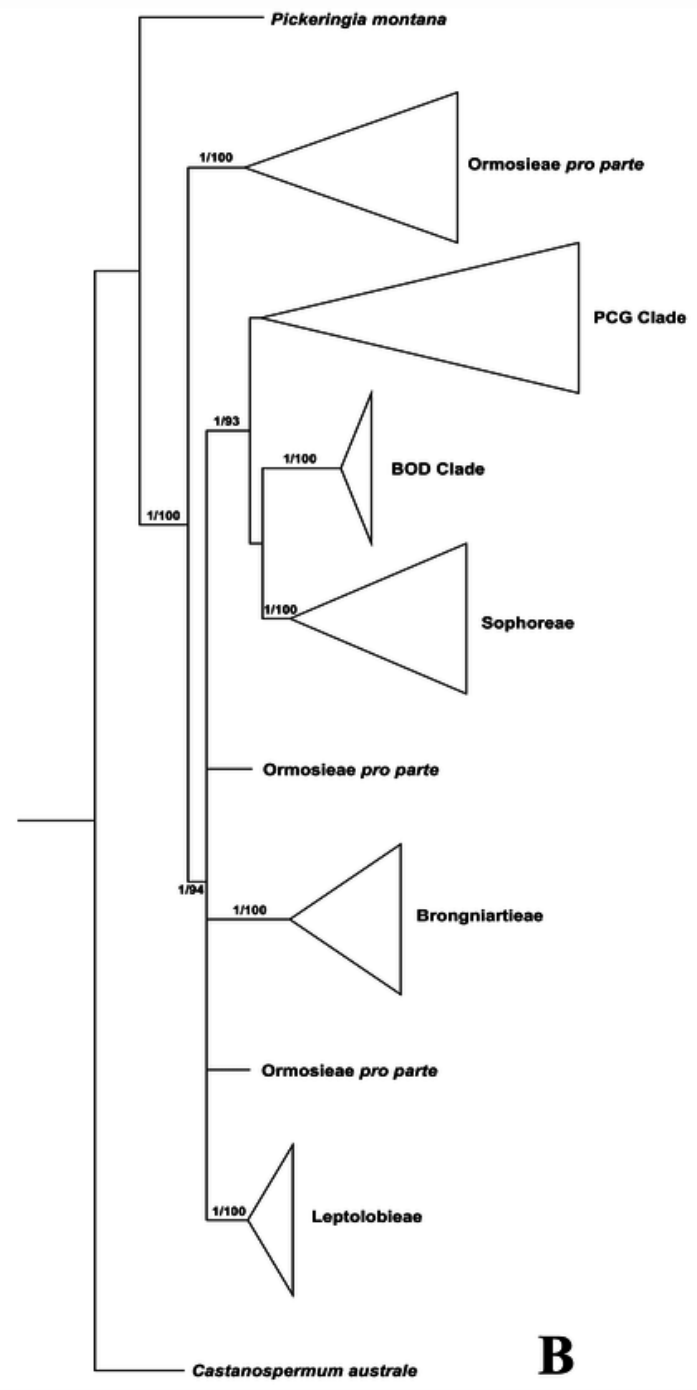




\section{Figure 2 (on next page)}

Figure 2. Bayesian tree of the concatenated nuclear ITS data, showing Sophoreae and its allies.

Bayesian posterior probabilities and maximum likelihood bootstrap values are given above the branches. 


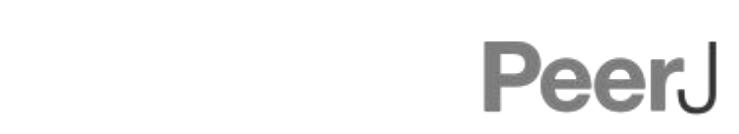




\section{Figure 3 (on next page)}

Figure 3. Bayesian tree of the concatenated plastid data of matK, rbcL, trnL-trnF and psbA-trnH sequences, showing Sophoreae and its allies.

Bayesian posterior probabilities and maximum likelihood bootstrap values are given above the branches. 

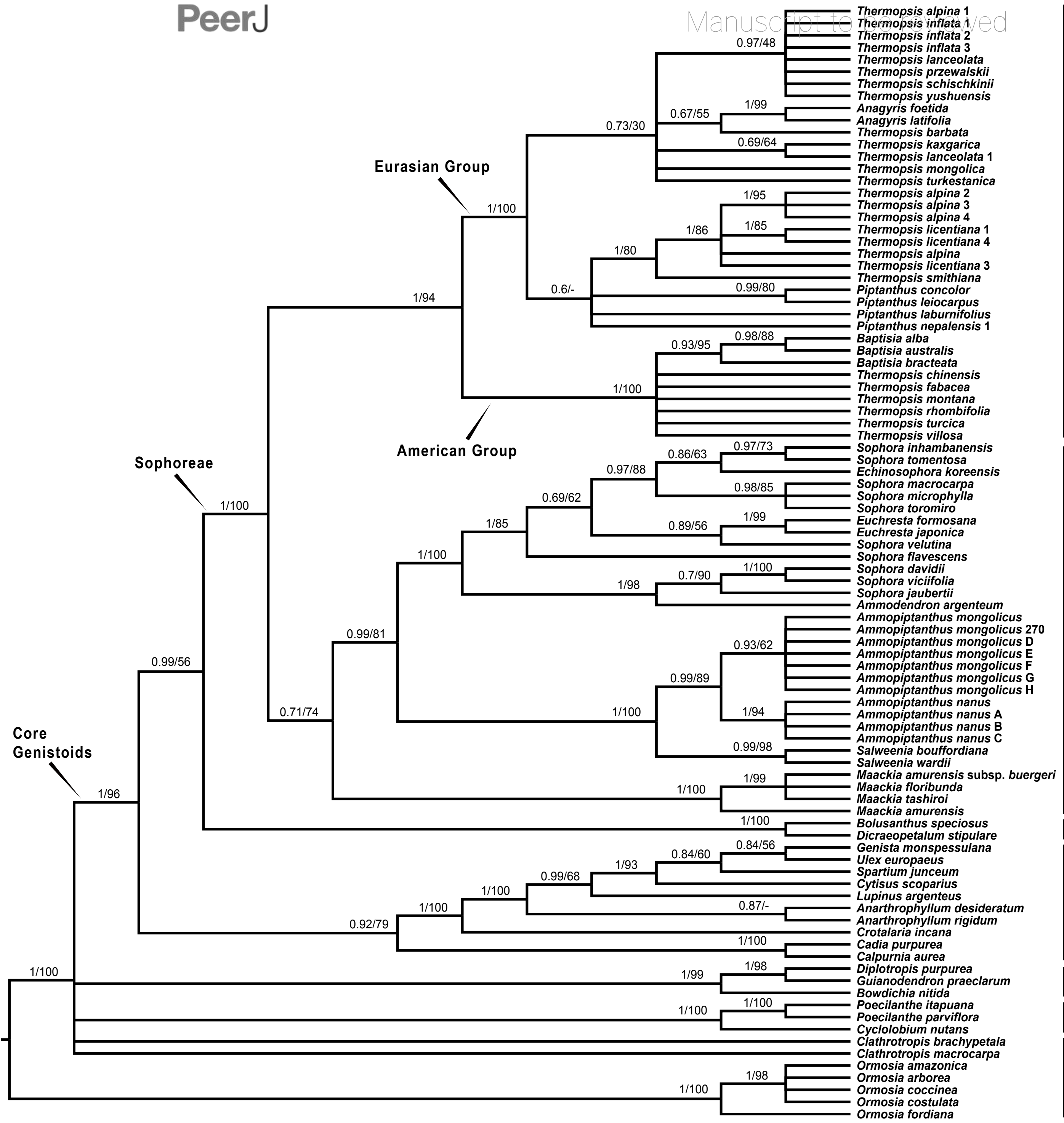

Thermopsoid Clade

Sophoroid

Clade

BOD Clade

PCG Clade

Leptolobieae

Brongniartieae

Ormosieae 


\section{Figure 4(on next page)}

Figure 4. Divergence times for Sophoreae/Themopsideae genera estimated by using BEAST based on the ITS dataset. Calibration points are marked by A-D.

Node labels and bars represent the estimated mean ages (in Ma) and their 95\% highest

posterior density intervals. Node I, II and III represent the divergence ages of $26.96 \mathrm{Ma}, 4.74$ $\mathrm{Ma}$ and $2.04 \mathrm{Ma}$, respectively. 
Thermopsis mongolica

Thermopsis yushuensis

Anagyris foetida

Anagyris foetida

Anagyris latifolia

Piptanthus nepalensis
Piptanthus tomentosus

Piptanthus tomentosus
Piptanthus nepalensis

$[$ Piptanthus laburnifolius

Piptanthus concolor

Piptanthus leiocarpus

Piptanthus leiocarpus

Thermopsis barbata

Thermopsis barbata

Thermopsis alpina

Thermopsis licentia
Thermopsis inflata

Thermopsis smithiana

Thermopsis macrophylla

D

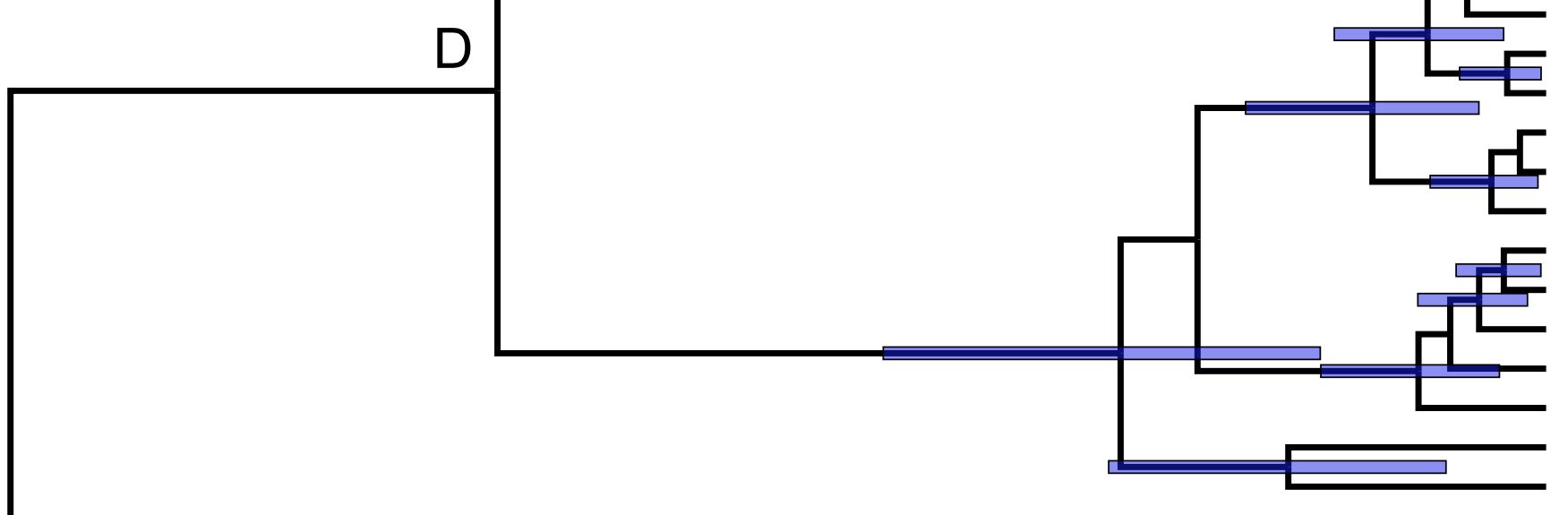

Thermopsis divaricarpa

Thermopsis villosa

Thermopsis fabacea

Thermopsis montana

Thermopsis rhombifolia var. ovata

Baptisia sphaerocarpa

Baptisia australis

Baptisia bracteata

Baptisia cinerea

Baptisia alba

Thermopsis turcica

Thermopsis chinensis

Sophora raivavaeensis

[ Sophora toromiro

Sophora howinsula

Sophora howinsula
Sophora microphylla

Sophora prostrata

Sophora tetraphylla

Sophora macrocarpa

Sophora inhambanensis

Sophora tomentosa

Sophora flavescens

Ammothamnus lehmannii

Ammodendron conollyi

Sophora velutina

Sophora davidii

Sophora jaubertii

Ammopiptanthus mongolicus 270

Ammopiptanthus mongolicus $\mathrm{E}$

Ammopiptanthus mongolicus $\mathbf{G}$

Ammopiptanthus mongolicus

Ammopiptanthus mongolicus $\mathrm{F}$

11 Ammopiptanthus mongolicus $\mathrm{H}$

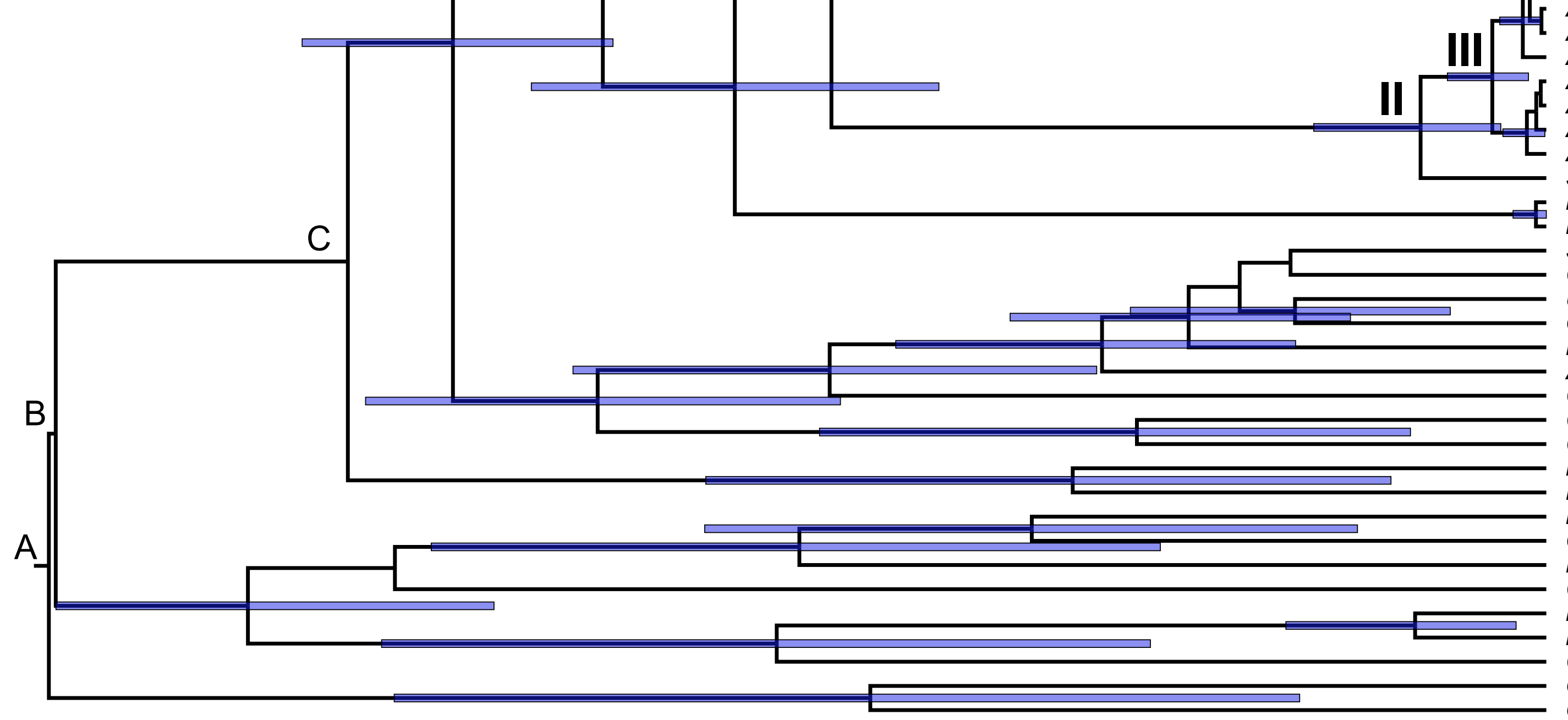

Ammopiptanthus mongolicus D

Ammopiptanthus nanus C

Ammopiptanthus nanus

Ammopiptanthus nanus A

Ammopiptanthus nanus B

Salweenia wardii

Maackia amurensis

Maackia chinensis

Spartium junceum

Cytisus scoparius

Ulex europaeus

Genista monspessulana

Lupinus argenteus

Anarthrophyllum rigidum

Crotalaria incana

Cadia purpurea

Calpurnia aurea

Bolusanthus speciosus

Dicraeopetalum mahafaliense

Bowdichia nitida

Guianodendron praeclarum

Diplotropis purpurea

Clathrotropis brachypetala

Poecilanthe itapuana

Poecilanthe parviflora

Cyclolobium nutans

Ormosia amazonica

Ormosia fordiana 
Figure 5 (on next page)

Figure 5. Distribution (A) and representative plants of Ammopiptanthus $(B \& C)$ and Salweenia (D).

A: red - Ammopiptanthus (I: distribution of A. mongolicus; II: distribution of $A$. nanus), green Salweenia; B: Ammopiptanthus mongolicus; C: Ammopiptanthus nanus; D: Salweenia wardii. 


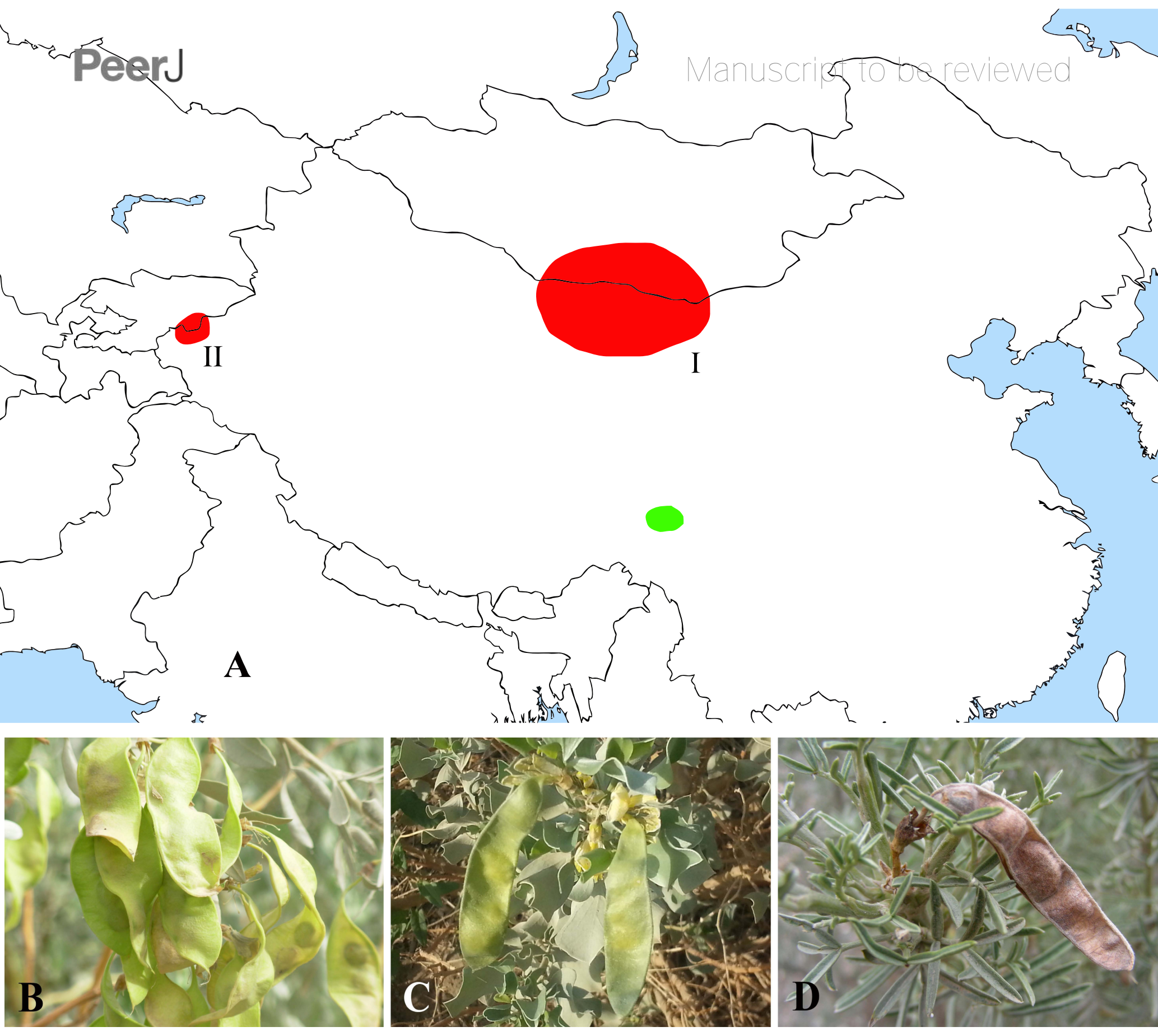

